DOI: 10.17951/rh.2018.46.219-233

\author{
Anna Jankowska-Nagórka \\ (Uniwersytet Pedagogiczny im. Komisji Edukacji Narodowej w Krakowie) \\ https://orcid.org/0000-0003-4451-1286
}

\title{
Zmiana imion i nazwisk autochtonów na Dolnym Śląsku jako wyraz antyniemieckiej polityki państwa w latach 1945-1949. Kilka refleksji o sposobach postępowania władz
}

\author{
Changing the Names and Surnames of Indigenous Inhabitants of Lower Silesia \\ as an Anti-German State Policy of Poland from 1945 to 1949. \\ Some Remarks on Government Actions
}

\section{STRESZCZENIE}

Celem artykułu jest przedstawienie jednego ze sposobów usuwania śladów niemczyzny, jakim było zmienianie na polsko brzmiące imion i nazwisk autochtonów mieszkających na Dolnym Śląsku. Różne procesy dziejowe miały wpływ na to, że autochtoni nosili imiona i nazwiska zgermanizowane. Dokumenty powojenne szczebla powiatowego i wojewódzkiego wskazują na przeprowadzanie tej procedury bezprawnie. Po pierwsze, cała akcja zainicjowana została przez okólnik Ministerstwa Ziem Odzyskanych, a nie akt prawny rangi ustawy. Po drugie, zmiana ta odbywała się z użyciem przymusu państwowego, realizowanego przez urzędników różnych rang. Przymusem tym były sankcje administracyjne, grzywna, a w niektórych przypadkach sięgano nawet do ingerencji w życie prywatne obywateli. W powojennej rzeczywistości, gdzie zwalczano wszystko, co miało związek z niemczyzna, akcja zmiany imion i nazwisk na Ziemiach Odzyskanych była elementem polityki antyniemieckiej ówczesnych władz.

Słowa kluczowe: Ziemie Odzyskane, Śląsk, zmiana imion i nazwisk, autochtoni

Niniejszy artykuł ma na celu przedstawienie zjawiska zmiany imion i nazwisk ludności rodzimej zamieszkującej powojenny Dolny Śląsk. W okresie 1945-1949, a więc wtedy, gdy istniało Ministerstwo Ziem Odzyskanych, doszło do bezprecedensowej akcji polonizacji nazwisk niemieckich bądź zniemczonych $\mathrm{u}$ autochtonów. Często zmiana nazwiska bądź 
imienia była przeprowadzana naprędce, przy użyciu przymusu. Chociaż dokonywano tego na całym obszarze Ziem Odzyskanych, to należy zauważyć, że Dolny Śląsk był regionem specyficznym, gdzie zamieszkiwało znacznie mniej ludności rdzennej niż np. na Górnym Śląsku. Na Górnym Śląsku pod rządami wojewody Aleksandra Zawadzkiego zmiana imion i nazwisk przybrała najbardziej opresyjny charakter i była najbardziej rozległa $\mathrm{w}$ czasie $^{1}$. W artykule pominięto tematykę zmiany imion i nazwisk w "starej” części Polski, gdyż te były przeprowadzane na innej podstawie prawnej (dekret o zmianie imion i nazwisk) oraz miały związek bezpośrednio z okupacją niemiecką i jej następstwami.

Wraz z nadejściem władzy polskiej na Ziemiach Odzyskanych realnie pojawił się problem mieszkających tam Polaków lub osób pochodzenia polskiego bądź słowiańskiego. Z jednej strony nowej władzy zależało na pozyskaniu tej grupy ludności jako argumentu dla powrotu Ziem Odzyskanych do Macierzy, jednak z drugiej strony ówczesna ekipa rządząca traktowała autochtonów podejrzliwie, dlatego że zamieszkiwali oni Rzeszę, co w jej oczach niejako ex definitione rodziło możliwość sprzeniewierzenia się wobec nowych władz.

Powojenna polityka prowadzona na obszarze nowych nabytków terytorialnych zmierzała do unifikacji z resztą kraju, ale również do repolonizacji tamtych stron. Był to proces w jakimś sensie odwrotny wobec $t z w$. korienizacji prowadzonej w Związku Radzieckim w latach dwudziestych i jeszcze na początku lat trzydziestych ubiegłego stulecia. Później Józef Stalin nakazał odejście od korienizacji, której istota - przynajmniej werbalnie, a może lepiej propagandowo - polegać miała na wspieraniu kultury oraz języków narodów wchodzących w skład ZSRR². Rozpoczął się, niekiedy brutalny, okres unifikacji wszystkich narodowości zamieszkujących imperium Józefa Stalina i tworzenie „człowieka radzieckiego”, owego słynnego homo sovieticus. W tym ostatnim kontekście można doszukać się

1 Archiwum Państwowe w Katowicach, Śląski Urząd Wojewódzki, Wydział Administracyjno-Prawny, sygn. 79, Polszczenie imion i nazwisk 1946-1948, wiele dokumentów dotyczących tej procedury. Również bogata literatura opisuje to zjawisko, a najbardziej gruntownie B. Linek, Polityka antyniemiecka na Górnym Ślasku w latach 1945-1950, Opole 2014, passim.

2 Zоb. О.И. Чистяков, Коренизациия государственного аппарата национальных районов в первые годы советской власти: По материалам нацииональных районов Среднего Поволжья, „Правоведение” 1965, 1, s. 164-168; Е.Ю. Борисенок, Феномен советской украинизацчии. 1920-1930-е г2., Москва 2006, passim; idem, Концеепциии «украинизацчии» и их реализация в национальной политике в государствах восточноевропейского региона (1918-1941 22.), Автореферат диссертации на соискание ученой степени доктора исторических наук (на правах рукописи), Москва 2016, s. 17-41, http://inslav.ru/images/ stories/other/aspirantura/borisenok/borisenok_avtoreferat.pdf [dostęp: 7 I 2018]. 
pewnych podobieństw w zwalczaniu przez rodzimych polskich komunistów wszelkich przejawów niemczyzny w odmiennościach językowych czy też brzmieniu imion, nazwisk oraz nazw własnych. Choć z drugiej strony, dla państw niekomunistycznych, ale również dyktatorskich, stałą praktyką było dążenie do ujednolicania społeczeństw, jak np. próby wyrugowania języka euskara (baskijskiego) w frankistowskiej Hiszpanii czy walka z mniejszościami we Włoszech Benita Mussoliniego poprzez najrozmaitsze zakazy dla ich języków (niemiecki, słoweński i chorwacki). Są wszakże i znaczące różnice wynikające w pierwszym rzędzie z prób repolonizacji osób zamieszkujących Ziemie Odzyskane i posiadających polskie czy słowiańskie korzenie. Nie należy też zapominać o wszechobecnej w powojennych latach niechęci do wszystkiego co niemieckie lub z niemieckością mogące się kojarzyć. Szeroki zakres pojęcia repolonizacji prowadził do wielu akcji, popieranych przez oficjalne czynniki rządowe, zmierzające do tępienia śladów niemczyzny i "przywracania” polskiego oblicza Ziem Odzyskanych. Jedną z takich akcji było zmienianie imion i nazwisk autochtonów na polsko brzmiące.

Pierwszą publiczną próbę napiętnowania imion niemieckich stanowił artykuł, który ukazał się jeszcze w marcu 1945 r. w katowickim „Dzienniku Zachodnim”. W publikacji zatytułowanej Złowrogie imiona autor dosadnie przedstawił nazwanie kogoś imieniem germańskim jako wstyd:

Wszystko, co trąci niemczyzna, jest dla nas równie wstrętne jak jakiś brzydki zapach. Dlatego też te germańskie imiona nam po prostu śmierdzą. Wiemy, że ci, co je nosza, nie są temu winni. Imiona takie przeważnie były narzucane, ba, ostatnio nawet przymusowo nadawane. Nie zmienia to jednak postaci rzeczy, że plamią one niejednego Bogu ducha winnego Polaka przez całe życie i narażają na pośmiewisko ${ }^{3}$.

Dalej autor konkluduje, że potrzebna jest ustawa o zmianie imion, która dałaby szansę wyjścia z impasu „napiętnowanym” osobom. Patrząc na zanik w skali europejskiej imienia Adolf po wojnie, nie dziwi tuż powojenna walka z imionami germańskimi, które autor artykułu przytacza przykładowo (Kurt, Zygfryd, Reinhold, Wilibald, Hildegarda, Edeltraude, Irmgard, Berta). Nie tylko na Ziemiach Odzyskanych te imiona wydawały się nie na miejscu. Wielu obywateli przestało być Adolfami. W okresie powojennym na terenie Polski tylko kilkorgu dzieciom nadano imię Adolf, w przeciwieństwie do imienia Józef, które było po wojnie popularne (w pewnym okresie utrzymywało się na szóstej pozycji wśród najbardziej popularnych imion męskich w Polsce), a dzisiaj przeżywa swój renesans. To też daje do myślenia, jak odgórnie sterowano zbiorową świa-

3 Niejaki X, Złowrogie imiona „Dziennik Zachodni” 22 III 1945, 39, s. 2. 
domością społeczeństwa, że imię dyktatora i zbrodniarza, Stalina, w równym stopniu odpowiedzialnego za masowe zbrodnie, nie doznało takiego moralnego uszczerbku, jak imię Hitlera. Być może jednym z powodów takiego stanu rzeczy był kontekst religijny, to znaczy osobom nadającym dziecku imię kojarzyło się ono z jednym z najbardziej czczonych świętych w Kościele, opiekunem Jezusa, a święty Adolf był mniej znany, więc imię to kojarzyło się jednoznacznie. W przedwojennej Polsce natomiast imię Adolf i Adolfina były dość popularne 4 .

W jaki zatem sposób uregulowano ten problem prawnie? Wszak imię i nazwisko stanowi najbardziej osobistą sferę człowieka. Wiąże się ze zmianami we wszystkich dokumentach. Aby przyspieszyć procedurę zmiany imion i nazwisk, Ministerstwo Ziem Odzyskanych wydało Okólnik nr 22/48 z dnia 8 maja 1948 r. o zmianie i ustalaniu imion i nazwisk. W powyższym akcie prawa wewnętrznego, bo nie była to ani ustawa, ani rozporządzenie, odnaleźć można wiele rozwiązań, które z punktu widzenia dzisiejszego rozumienia praw i obowiązków obywatelskich są trudne do przyjęcia. W punkcie trzecim np. jest mowa o tym, że wniosek o spolszczenie imienia bądź nazwiska należy spisywać natychmiast, a raz złożone oświadczenie woli nie może być cofnięte. $W$ kolejnym punkcie minister Ziem Odzyskanych nakazał swym podwładnym, by:

Osoby nie wykazujące specjalnie złej woli, a tylko nieświadomość względnie przyzwyczajenie do niemieckiego nazwiska, należy uświadomić, przekonać i wskazać na dobrodziejstwa omawianej ustawy, która zezwala obywatelowi polskiemu spolszczyć lub zmienić nazwisko na polskie. O osobach wykazujących jawnie złą wolę w tym kierunku, należy donieść Starostwu ${ }^{5}$.

Dalej, w tym samym punkcie, zastosowano sankcje za niechęć do zmiany imienia bądź nazwiska, powołując się na art. 18 prawa o wykroczeniach, czyli naganę z ostrzeżeniem, zmianę mieszkania na gorsze, zwolnienie z urzędu, cofnięcie koncesji lub nawet grzywnę do 30 tys. zł. Okólnik nie definiuje do końca słów „przymus” czy „presja” zawartych w sprawozdaniach starostów. Po prostu państwo pod jakże szlachetnym hasłem repolonizacji nie pozostawiało obywatelom wyjścia, tylko drogą ordynarnej groźby, w majestacie prawa, dążyło do podporządkowania obywateli w najbardziej osobistej sferze - własnego imienia bądź nazwi-

4 M. Malec, Imię w polskiej antroponimii i kulturze, Kraków 2001, s. 75-76; Słownik imion wspótcześnie używanych, red. K. Rymut, Kraków 1995, s. 5.

5 Okólnik nr 22/48 z dnia 8 maja 1948 o zmianie i ustalaniu imion i nazwisk, Archiwum Państwowe we Wrocławiu [dalej: APWr], Urząd Wojewódzki Wrocławski [dalej: UWWr], sygn. V/174, Sprawy zmiany nazwisk i imion 1948-1949, 25 V 1948, numer karty nieczytelny. 
ska. A wszystko to odbywało się w atmosferze powszechnego wskazywania na pozytywną rolę autochtonów - że byli wytrwali, nie dali się zgermanizować itd. Mimo wszystko władza dążyła do ujednolicania społeczeństwa - nawet przez spolszczanie nazwisk.

Niemcy, wcześniej, nie tylko w czasach hitlerowskich, zmieniali imiona i nazwiska Ślązaków na brzmiące bardziej niemiecko niż dotychczas i w ten sposób tworzyli „rdzennych” Niemców zamieszkujących Śląsk Poniższy cytat nie wymaga żadnego komentarza:

W naszem mieście [tj. na Śląsku w Tarnowskich Górach - A.J.-N.], odbyła się dnia 10 listopada 1743 roku rejestracja mieszkańców przez pruskich komisarzy i od tego czasu zaczyna się głównie przekręcanie i zniekształcenie pisowni polskich nazwisk. Przytaczam n.p. nazwisko Stefański; widziałem czarno na białem własnoręczny podpis w bezbłędnej pisowni, lecz na tej samej karcie zapis pruskiego urzędnika w sposób najordynarniejszy "Stephainsky", więc jednym zamachem w pięknem polskiem nazwisku aż pięć błędów. Nie koniec na tem: w dalszym ciągu protokółu już zmienił całe nazwisko i pisze już całkiem krótko „Stephan”. Tak z Polaka powstał Niemiec. Niektóre polskie nazwiska przekręcano do niezapoznania n.p. zamiast Szedoń napisał urzędnik Schädler, zamiast Rajczyk zaś Reitzig i samowolnie przechrzcił Polaków na „rodowitych Niemców”. Nazwiskom kończącym się na „a" lub „ek”, chętnie dodawano końcowkę „, $\mathrm{e}^{\prime \prime}$ lub „,ke”, przez co powstały nazwiska o brzmieniu niemieckiem, n.p. Hanke, Kloske, Koske, Benke, Wanke, Kolitschke, Gurike i.t.d. Wypadków takich można na setki wyliczyć ${ }^{7}$.

Nie tylko obserwacje jednej osoby, ale także badania bliższe czasom współczesnym dowodza, że takie zmiany w imionach i nazwiskach były praktyką powszechną wśród urzędników niemieckich na całym Śląsku Zapowiedź konkretnych działań władz również odzwierciedlała prasa, wzmiankując o procedurze zmiany imienia bądź nazwiska tymi słowy: „Nie chcą niemieckich imion i nazwisk" nizowania ludności polskiej przez przekręcanie nazwisk i konieczność nadawania niemieckich imion dzieciom. W jaki sposób to zorganizowano? Po pierwsze, uproszczono tryb postępowania w sprawach spolszczania imion i nazwisk oraz zwolniono osoby starające się o taką zmianę z opłat skarbowych, nie było też postawionego wymogu zachowania terminu ${ }^{10}$. Po drugie, nadano tej sprawie priorytet $\mathrm{w}$ ten sposób, że wojewoda zobligował podległych mu starostów: „Z uwagi na ważność akcji w dziele wal-

6 J. Nowak, Kronika miasta i powiatu Tarnowskie Góry: najstarsze dzieje Ślaska i ziemi Bytomsko-Tarnogórskiej: dzieje pierwszego górnictwa w Polsce, Tarnowskie Góry 1927.

7 Ibidem. Śląsku.

H. Borek, Wśród ślaskich nazw, Opole 1986, s. 77 i nn. dotyczą nazw osobowych na

9 Nie chca niemieckich imion i nazwisk, „Słowo Polskie” 7 III 1947, 64, s. 5.

10 APWr, UWWr, sygn. V/174, Pismo Naczelnika Wydziału Administracyjno-Prawnego do Starostów i Prezydentów Miast w sprawie zmiany imion i nazwisk, 22 X 1948, k. 3. 
ki z przejawami niemczyzny na Ziemiach Odzyskanych czynię OB. OB. Starostów Powiatowych i Prezydentów miast osobiście odpowiedzialnymi za pozytywny i pełny jej wynik"11. Akcja miała zakończyć się sprawozdaniami z działań podjętych przez starostów ${ }^{12}$.

Sprawą zmiany imion i nazwisk zajmował się urząd wojewódzki jako organ administracji państwowej w terenie oraz poszczególne starostwa, natomiast różnymi akcjami antyniemieckimi - wydziały Urzędu Wojewódzkiego Wrocławskiego: VI Społeczno-Polityczny (np. Archiwum Państwowe we Wrocławiu, sygn. VI/308 - różne sprawy narodowościowe 1948-1949, VI/311 - repolonizacja, sprawozdania 1947, VI/324 - sprawy autochtonów 1947) i V Administracyjno-Prawny (np. Archiwum Państwowe we Wrocławiu, sygn. V/158 - stwierdzenie polskiej przynależności narodowej 1947), a także Wydział I Ogólny (np. Archiwum Państwowe we Wrocławiu, sygn. I/87 - ustalanie nazw miejscowości 1948, I/83 - usunięcie śladów niemczyzny 1945). Stąd niekiedy występowało krzyżowanie się zakresów ich kompetencji. Kwestia zmiany imion i nazwisk leżała w gestii wyłącznie Wydziału Administracyjno-Prawnego. Było to związane ze zmianami w aktach stanu cywilnego, które z kolei znajdowały się w posiadaniu starostw. Jakie były wyniki odniemczania imion i nazwisk, można dowiedzieć się ze sprawozdań poszczególnych starostów dolnośląskich. I tak starosta brzeski w sprawozdaniu do wojewody z 16 września 1948 r. informował o tym, że złożono dotąd 62 protokoły o zmianę nazwisk i 15 protokołów o zmianę imion. Akcja w owym czasie nie była jeszcze zakończona ${ }^{13}$. Znamienne jest, w jaki sposób starosta traktował tę procedurę:

Nadto zainteresowany tą akcją Polski Związek Zachodni w Brzegu sporządził odpowiednie afisze do ludności autochtonicznej o nazwiskach niemieckich, by zrzuciła z siebie piętno niemczyzny. [...] Ludność stale zamieszkała na terenach Ziem Odzyskanych chętnie porzuca niemieckie nazwiska i imiona ${ }^{14}$.

Zdziwienie budzi fakt chętnego rezygnowania z niemieckich imion i nazwisk, zwłaszcza w świetle sprawozdań kolejnych starostów. Zgoła odmienne wrażenie odnieść można po zapoznaniu się ze sprawozdaniem starosty bystrzyckiego. Na wstępie powołał się on na dekret o zmianie imion i nazwisk, następnie podał czynności, jakich dokonał w związku z otrzymaniem polecenia od wojewody. Na końcu zaś stwierdzał:

\footnotetext{
11 Ibidem, Pismo wojewody w sprawie zmiany i ustalania imion i nazwisk, 12 VI 1948, k. 7.

12 Ibidem.

13 Ibidem, Sprawozdanie starosty brzeskiego dla wojewody na temat zmiany imion i nazwisk, 16 IX 1948, k. 36.

14 Ibidem.
} 
Ponieważ do dnia 30 września 1948 r., do tut. Starostwa, wpłynęły zaledwie dwa wnioski, przystąpiłem do akcji przymusowej spolszczenia nazwisk i imion tych obywateli, którzy dotychczas nie wnieśli dobrowolnie wniosków. Ze względu na dużą ilość osób, co do których trzeba będzie zastosować przymus, proszę o przesunięcie terminu zakończenia akcji do dnia 31 października 1948 r. ${ }^{15}$

Sformułowanie o stosowaniu przymusu w procedurze administracyjnej w piśmie urzędnika państwowego do swojego przełożonego, przedstawiciela rządu $\mathrm{w}$ terenie, jest nie tylko kuriozum, ale również dowodem, jak zajmowano się sprawami pozbywania się niemczyzny. Była ona traktowana jako zjawisko, które należało wyrugować do cna, nawet za cenę niszczenia wolności osobistej obywatela zgodnie $\mathrm{z}$ oficjalną polityką rządowa, której jednym z haseł była antyniemieckość ${ }^{16}$. Możemy domniemywać, że słowo „przymus” dla starosty bystrzyckiego nie oznaczało vis absoluta, a mogło jedynie chodzić o wezwanie z urzę$\mathrm{du}$ „opornego" petenta, ewentualnie poparte zjawieniem się milicjanta $\mathrm{w}$ miejscu pracy lub zamieszkania. $\mathrm{Z}$ kolei w sprawozdaniu starosty dzierżoniowskiego dominuje inny wydźwięk pisma: „[...] na ogół ludność zainteresowana ustosunkowuje się przychylnie do zmiany nazwisk $\mathrm{i}$ imion i jak dotychczas nie napotykano na opór" ${ }^{\prime \prime}$. Jest to zupełne przeciwieństwo poprzednich sprawozdań i aż trudno uwierzyć, że w powiecie dzierżoniowskim przychylnie ustosunkowano się do tak wielkiej zmiany, jak narzucone odgórnie nowe brzmienie własnych imion i nazwisk. W powiecie głogowskim na ogólną liczbę 23 osób noszących imiona lub nazwiska cudzoziemskie wśród ludności rodzimej 13 zgodziło się na zmianę nazwiska dobrowolnie, 10 odmówiło, a 1 osoba zmieniła imię, pozostawiając nazwisko o brzmieniu polskim ${ }^{18}$. W tym przypad-

15 Ibidem, Sprawozdanie starosty bystrzyckiego dla wojewody na temat zmiany imion i nazwisk, 7 X 1948, k. 37.

16 Już wkrótce po zakończeniu wojny, na spotkaniu z dziennikarzami w Ambasadzie Polski w Moskwie 26 czerwca 1945 r., Władysław Gomułka i Stanisław Mikołajczyk jasno określili stanowisko wobec problemu niemieckiego na Ziemiach Odzyskanych, to znaczy zamanifestowali chęć budowania państwa jednorodnego narodowościowo - Odzyskane ziemie czekają na Polaków, „Dziennik Polski” 2 VII 1945, 145, s. 3. Ślady niemczyzny próbowano także odgórnie niwelować, np. nauczanie języka niemieckiego w szkołach - W sprawie nauczania języka niemieckiego, „Rzeczpospolita” 1 VI 1945, 144, s. 3. Również kierunek polityki został jednoznacznie wytyczony - „Tematyka demokratyczna, antyniemiecka i słowiańska fundamentem nowej szkoły polskiej” - Pokłosie zjazdu oświatowego w Łodzi, „Dziennik Polski” 2 VII 1945, 145, s. 7. Najbardziej widoczną formą odniemczania, związaną również z racją stanu, była zmiana nazw miejscowości na terytorium Ziem Odzyskanych.

17 Ibidem, Sprawozdanie starosty dzierżoniowskiego dla wojewody na temat zmiany imion i nazwisk, 16 IX 1948, k. 38.

18 Ibidem, Sprawozdanie starosty głogowskiego dla wojewody na temat zmiany imion i nazwisk, 15 IX 1948, k. 39. 
ku również $\mathrm{w}$ toku było postępowanie wobec opornych. Na szczerość zdobył się jedynie starosta górowski, który zawiadomił wojewodę, że na terenie powiatu mieszkało niewielu autochtonów, bo zaledwie ok. 200, z czego połowa nosiła nazwiska nieniemieckie, ale tylko 9 obywateli zdecydowało się na takie zmiany ${ }^{19}$. Również i on znalazł sposób na rozwiązanie tego problemu. W sprawozdaniu zapowiadał, że: „W związku z tym jestem zmuszony wezwać do Starostwa wszystkie osoby, których omawiana sprawa dotyczy, skłonić je do wyrażenia zgody na zmianę nazwisk i wnioski wypełnić na miejscu" ${ }^{20}$. W tym powiecie więc "skłaniano" obywateli do zmiany imion i nazwisk, jednakże nie wiadomo, jakim sposobem, bowiem starosta o nim nie wspomina. Jeśli wzywał do urzędu, to możliwe, że sama powaga starostwa i wezwanie wystarczyły do przekonania obywatela do zmiany nazwiska czy imienia. Ale to już jest jawne przyznanie się do stosowania przez państwo przymusu. $\mathrm{W}$ omawianych przypadkach żaden $\mathrm{z}$ tych starostów nie wspomniał o pomocy milicji czy Urzędu Bezpieczeństwa w tej kwestii, więc może nie używano przymusu w rozumieniu przemocy fizycznej, a raczej było to działanie psychologiczne, w znaczeniu pozytywnym (prośba, życzenie) bądź negatywnym (groźba, szantaż). Nie natrafiłam w tym zbiorze dokumentów na jakiekolwiek skargi na działanie starostów płynące od petentów do urzędu wojewódzkiego. Można to wytłumaczyć tym, że wielu było autochtonów zastraszanych lub traktowanych jak obywatele drugiej kategorii. Także wiele osób spośród rdzennej ludności nie miało świadomości prawnej dorównującej poziomem wiedzy urzędników. Ponadto niektórzy autochtoni słabo władali językiem polskim, o czym także jest mowa w sprawozdaniach starostów ${ }^{21}$.

Zupełnie nowe argumenty o niechęci do zmiany imienia lub nazwiska podał starosta jeleniogórski. Otóż, co już wiadomo z wcześniej przytaczanych sprawozdań, według dokumentów płynących ze starostwa „ludność rodzima nie bardzo chętnie poddaje się repolonizacji swoich dotychczasowych nazwisk" ${ }^{\prime 22}$. Tutaj nowością jest uzasadnienie tej niechęci przez powołanie się osób o zniemczonych nazwiskach na krewnych mieszkających w centralnej Polsce, na których nie nałożono obowiązku zmiany nazwisk ${ }^{23}$. Być może autochtoni chcieli w ten sposób wyrazić swoje stano-

19 Ibidem, Sprawozdanie starosty górowskiego dla wojewody na temat zmiany imion i nazwisk, 5 X 1948, k. 40.

${ }_{20}$ Ibidem.

21 Ibidem.

${ }^{22}$ Ibidem, Sprawozdanie starosty jeleniogórskiego dla wojewody na temat zmiany imion i nazwisk, 17 IX 1948, k. 42.

${ }^{23}$ Ibidem. 
wisko w sprawie zmuszania do zmiany imion i nazwisk na Ziemiach Odzyskanych: nie jesteśmy obywatelami drugiej kategorii, dlatego że mamy niemiecko brzmiące nazwiska. A przepisy (zasady postępowania) powinny być dla wszystkich obywateli takie same.

Bardziej stanowcze $\mathrm{w}$ wymowie antyniemieckiej jest sprawozdanie starosty kamiennogórskiego. Już na wstępie autor zaznaczył: „Sprawa repolonizacji Ziem Odzyskanych drogą zacierania śladów niemczyzny obejmuje również zmianę nazwisk i imion o brzmieniu niepolskim (niemieckim)"24. Tutaj szczegółowo podano przebieg tej procedury u zweryfikowanych obywateli powiatu. Najpierw rozwieszono ogłoszenia o tym, że zmiana imienia lub nazwiska o brzmieniu niemieckim następuje $\mathrm{w}$ formie uproszczonej i nie wymaga uiszczania opłat skarbowych, lecz gdy tego typu zachęta władz nie odniosła skutku, starosta zdecydował się na imienne wezwania i przygotowanie zawczasu gotowych protokołów ${ }^{25}$. Oporne przypadki wystąpiły również w starostwie kożuchowskim, gdzie starosta postąpił podobnie jak jego koledzy z innych powiatów, z tym że pozwolił sobie na większą szczerość niż poprzednicy, tłumacząc w sprawozdaniu adresowanym do wojewody: „W wypadkach opornych nie zastosowano jednakże żadnych poważnych presji, gdyż ludzie ci wezwani do tutejszego Urzędu gdzie sprawę naświetlono im ze strony ogólno-państwowej wyrazili swą zgodę i po wypełnieniu wniosków podpisali je"26. Aż ciśnie się na usta pytanie, co miały oznaczać poważne presje. Odwiedziny milicjanta w zakładzie pracy czy może donos do Urzędu Bezpieczeństwa o nieobywatelskiej postawie? Zatem jakiego rodzaju presją jest wezwanie do urzędu? Interesujące jest, że w kolejnym już starostwie przymus i presja w czasie postępowania administracyjnego traktowano jako coś oczywistego. I, co więcej, nie odnotowano skarg autochtonów na taką procedurę. Można z tego wysnuć wniosek, że skargi takie były, ale uciszane przez inne organy, zgoła nieadministracyjne. Możliwe jest też, że ich nie składano z obawy przed presją.

Zupełnie odmienne okazuje się sprawozdanie starosty legnickiego. Jego autor nie tylko nie wspomina o zastosowaniu przymusu czy presji, lecz podaje liczby składanych wniosków wraz z przykładami typowych zmian dokonywanych przez autochtonów: „Wszystkich osób, które otrzymały stwierdzenie polskiej przynależności narodowej, posiadających nazwisko o brzmieniu niemieckim na terenie tutejszego powiatu jest

24 Ibidem, Sprawozdanie starosty kamiennogórskiego dla wojewody na temat zmiany imion i nazwisk, 29 IX 1948, k. 43.

25 Ibidem.

26 Ibidem, Sprawozdanie starosty kożuchowskiego dla wojewody na temat zmiany imion i nazwisk, 13 IX 1948, k. 44. 
15 rodzin i wszyscy do dnia 10 września złożyli wnioski o spolszczenie nazwisk i imion" ${ }^{\prime 2}$. Dalej w dokumencie informowano:

I tak n.p. ob. stale zamieszkujący na terenach Ziem Odzyskanych posiadający nazwisko o brzmieniu niemieckim Bischoff zmienia nazwisko na Biskupski, Kleim na Klimkowski itp. Ob. Kirschner, którego nazwisko ojciec zgermanizował chętnie powraca do dawnego polskiego nazwiska Wiśniewski. Jedna z sióstr zakonnych nazwisko Kusch, bez zezwolenia przełożonej zakonu nie mogła decydować o zmianie nazwiska, po uzyskaniu zgody pragnie mieć nazwisko o brzmieniu polskim (również i w pisowni) Kura ${ }^{28}$.

W starostwie lubańskim „ludność życzliwie odniosła się” do akcji zmiany imion i nazwisk, a wszystkich wniosków złożono $41^{29}$. Lakoniczność tego sprawozdania każe przypuszczać, że nie we wszystkich powiatach akcja odniemczania imion i nazwisk przebiegała w ten sam sposób. Powiat lubański jest granicą między Śląskiem a Łużycami, więc być może tutaj już zamieszkiwali Serbołużyczanie i byli bardziej spolegliwi przez doświadczenia w zwalczaniu ich kultury przez władze niemieckie. Jednak z akt starostwa nie dowiemy się, czy urzędnicy odpowiedzialni za akcję odniemczania mieli świadomość istnienia słowiańskiej wyspy w niemieckim morzu.

Sposób samego ustalenia brzmienia spolszczonego imienia lub nazwiska przedstawia w sprawozdaniu starosta lwówecki. Otóż zmiany dokonywał Referat Administracyjno-Prawny tamtejszego starostwa po uprzednim wezwaniu petenta do urzędu ${ }^{30}$. Na zakończeniu protokołu mamy niemal pedagogizującą notkę starosty:

W czasie spisywania protokołów zmiany imion i nazwisk stwierdzono, iż z pośród zweryfikowanych stosunkowo niewielu włada językiem polskim, wobec czego zwracano mówiącym po niemiecku uwagę na konieczność uczenia się mowy ojczystej, tym bardziej, że osoby te nosić będą obecnie polskie nazwiska i imiona ${ }^{31}$.

W tym jedynym sprawozdaniu jest adnotacja, jak postępowano z osobami, które kategorycznie odmówiły zmiany imion i nazwisk. Wówczas stosowano wspomniany już Okólnik Ministra Ziem Odzyskanych nr 22/48

27 Ibidem, Sprawozdanie starosty legnickiego dla wojewody na temat zmiany imion i nazwisk, 30 IX 1948, k. 46.

${ }^{28}$ Ibidem, Sprawozdanie starosty legnickiego dla wojewody na temat zmiany imion i nazwisk, 30 IX 1948, k. 46.

${ }^{29}$ Ibidem, Sprawozdanie starosty lubańskiego dla wojewody na temat zmiany imion i nazwisk, 24 IX 1948, k. 48.

30 Ibidem, Sprawozdanie starosty lwóweckiego dla wojewody na temat zmiany imion i nazwisk, 21 IX 1948, k. 52.

31 Ibidem, k. 52-54. 
z dnia 8 maja 1948 r., w którym następuje odwołanie się do przepisów art. 18 prawa o wykroczeniach.

Okólnik nie definiuje słów „przymus” czy „presja” zawartych w sprawozdaniach starostów. Po prostu państwo, pod jakże szlachetnym hasłem repolonizacji, nie pozostawiało obywatelom wyjścia, tylko drogą ordynarnej groźby, w majestacie prawa, dążyło do podporządkowania ich w najbardziej osobistej sferze - własnego imienia bądź nazwiska. A wszystko to przeprowadzane $\mathrm{w}$ atmosferze powszechnego wskazywania na pozytywną postawę autochtonów - że wytrwali, nie dali się germanizacji itd. Nie ulega zatem wątpliwości, że władza mimo wszystko dążyła do ujednolicenia społeczeństwa, choćby przez spolszczanie nazwisk.

Czy można oczekiwać odmiennych sprawozdań z innych powiatów? W starostwie namysłowskim również podkreślono, że na 94 autochtonów tylko 17 złożyło stosowne wnioski, co nie było rozwiązaniem, jakiego spodziewał się starosta ${ }^{32}$. Humanitarne podejście, moim zdaniem, zaprezentował starosta oleśnicki, który tłumaczył niechęć do zmiany imion i nazwisk niemieckich tym, że w przyszłości mogłyby wystąpić problemy z odnalezieniem krewnych o dotychczasowym nazwisku, co w głównej mierze dotyczyło osób starszych i samotnych ${ }^{33}$. Ze sprawozdania starosty oławskiego dowiadujemy się, że powiat zamieszkiwała bardzo nieliczna grupa ludności rodzimej ${ }^{34}$, jednakże informacja ta nie została poparta żadnymi liczbami. Starosta przyznał wprost, że żaden z podległych mu wójtów ani burmistrzów nie przysłał danych we wzmiankowanej sprawie ${ }^{35}$. Kolejne sprawozdanie, starosty średzkiego, wnosi do moich rozważań kwestię natury czysto praktycznej. Przekonywał on wojewodę, że powiat średzki był zamieszkany głównie przez ludność utrzymującą się z pracy na roli, co uniemożliwiało przeprowadzenie wymaganych formalności ${ }^{36}$. Zaiste trudny to do zrozumienia argument, bo nie wiadomo, czy mowa była o większym przywiązaniu chłopów do tradycji, czy też mniejszym wpływie urzędników na ludność parającą się rolnictwem i zamieszkującą położone dalej od starostwa wsie. Być może chodziło o obie kwestie albo starosta miał na myśli jeszcze inne przyczyny. W kolejnym zaś sprawo-

32 Ibidem, Sprawozdanie starosty namysłowskiego dla wojewody na temat zmiany imion i nazwisk, 15 IX 1948, k. 56.

${ }^{33}$ Ibidem, Sprawozdanie starosty oleśnickiego dla wojewody na temat zmiany imion i nazwisk, brak daty, k. 57-58.

${ }^{34}$ Ibidem, Sprawozdanie starosty oławskiego dla wojewody na temat zmiany imion i nazwisk, 15 IX 1948, k. 59.

35 Ibidem.

36 Ibidem, Sprawozdanie starosty średzkiego dla wojewody na temat zmiany imion i nazwisk, 29 X 1948, k. 60. 
zdaniu mamy do czynienia z niezrozumieniem przepisów. Starosta strzeliński chciał odniemczać nazwiska repatriantów i przesiedleńców, chociaż w okólniku wyraźnie podkreślono, że procedura uproszczona była zarezerwowana dla autochtonów ${ }^{37}$.

Starosta świdnicki przygotował z kolei grunt pod zmianę niemieckich imion i nazwisk poprzez szeroko zakrojoną akcję propagandową, do której zaangażował wszystkie ówcześnie istniejące organizacje społeczne, partie polityczne, a nawet proboszczów i Komitet Żydowski ${ }^{38}$. Sporządzono około 600 wniosków o repolonizację nazwisk, lecz nie przyniosło to spodziewanych rezultatów. Do 5 października wpłynęło zaledwie 46 podań, co starosta określił jako „wynik akcji wprost znikomy” ${ }^{39}$. Warte podkreślenia jest, że dopiero $\mathrm{w}$ tym sprawozdaniu mamy pełny obraz działań w zakresie spolszczania imion i nazwisk. Otóż na podstawie dekretu o zmianie imion i nazwisk należało zasięgnąć opinii powiatowego urzędu bezpieczeństwa publicznego. I w tym właśnie raporcie zawarta jest informacja o tym, że starosta wysłał pismo do szefa UBP w Świdnicy o usprawnienie wzmiankowanej procedury ${ }^{40}$.

Natomiast w sprawozdaniu z powiatu wałbrzyskiego starosta podkreślił konieczność zachowania poufności akcji w jej stadium przygotowawczym, bez jawnego rozgłosu i jakiegokolwiek nacisku ${ }^{41}$. Nie wiadomo, co takie poufne postępowanie miało oznaczać, albowiem we wszystkich poprzednich starostwach - przeciwnie - starano się nadać tej akcji publiczny charakter, a wręcz włączano do niej wszystkie organy państwa, angażując ponadto organizacje społeczne.

W jaki sposób można zatem podsumować akcję repolonizacji imion i nazwisk? Z dokumentów poszczególnych starostw nie wyłania się jednolity obraz przeprowadzanej akcji. Każdy ze starostów inaczej konstruował sprawozdanie, a co za tym idzie, znalazły się w nich różne zmienne, np. brak konkretnych przykładów zmiany imion i nazwisk (wyjątek stanowi sprawozdanie starosty legnickiego). W innym przypadku zostały podane tylko nazwiska niemieckie (starostwo lwóweckie). Nie wszystkie starostwa dostarczyły sprawozdania. Dodatkowym czynnikiem utrudniającym czytelność tych raportów jest fakt, że akcja ta miała charakter

37 Ibidem, Sprawozdanie starosty strzelińskiego dla wojewody na temat zmiany imion i nazwisk, 27 IX 1948, k. 61.

38 Ibidem, Sprawozdanie starosty świdnickiego dla wojewody na temat zmiany imion i nazwisk, 5 X 1948, k. 62-66.

39 Ibidem.

40 Ibidem.

41 Ibidem, Sprawozdanie starosty wałbrzyskiego dla wojewody na temat zmiany imion i nazwisk, brak daty, k. 69-75. 
propagandowy, więc niekiedy trudno oddzielić działania wynikające ściśle z przepisów obowiązującego wówczas prawa od samowolnych akcji urzędników, które dziś nazwalibyśmy dyskryminującymi czy wręcz bezprawnymi, chociaż i niektóre przepisy w świetle dzisiejszego funkcjonowania ochrony prawnej jednostki były jawnym pogwałceniem wolności. Z kolei, gdy przyjrzymy się bliżej szczeblowi miejskiemu i gminnemu, to można dostrzec pewne różnice przy zmianie imion i nazwisk, jednakże wszędzie była przestrzegana zasada instancyjności w postępowaniu administracyjnym. $Z$ archiwaliów wiadomo też, że niektóre decyzje administracyjne o repolonizacji personaliów były przeprowadzane nieprawidłowo. W Archiwum Państwowym w Legnicy znajduje się pismo starosty jaworskiego do wójta gminy Mściwojów, w którym jest mowa o zwrocie protokołu do gminy z racji wadliwie przeprowadzonej zmiany nazwiska Schram na Szramski. Według starosty było to pozostawienie obywateli w niepewności co do ich losu, a powinni oni mieć zaufanie do swojej ludowej ojczyzny. W powyższej sytuacji należało jego zdaniem zaproponować kilkanaście nazwisk polskich lub zainteresować się, czy obywatele będący w podobnej sytuacji nie mieli jakiegoś krewnego o polskim nazwisku. Taka sama zasada dotyczyła imion - np. nie można było dopuścić do zmiany imienia Rosemaria na Róża-Maria. W tym przypadku sprawa została odesłana do ponownego rozpatrzenia, a starosta dodatkowo pouczył, że wójt, urzędnicy stanu cywilnego i sołtysi:

[...] z tytułu swego charakteru służbowego, będąc w stałym kontakcie z obywatelami polskimi o nazwiskach i imionach o brzmieniu niemieckim, mają obowiązek $\mathrm{w}$ formie przekonywujących rozmów wpłynąć na tych obywateli, aby złożyli wnioski o zmianę nazwisk i imion $\mathrm{w}$ duchu i brzmieniu polskim ${ }^{42}$.

A zatem ze słów starosty można wywnioskować, że w powyższej grupie społecznej zabiegano o pozyskanie lojalnych obywateli, którzy czuliby się tak pewnie w Polsce, jak reszta społeczeństwa. Nie oznaczało to, że rezygnowano ze stosowania jawnego przymusu, co z kolei nie mogło wzbudzić pozytywnego nastawienia do nowej władzy, a wręcz przeciwnie, było jednym z czynników, które doprowadziły autochtonów do ucieczki od polskości. Było to szczególnie widoczne na Górnym Śląsku, gdzie dzieci czy wnuki powstańców śląskich były szykanowane za niemiecko brzmiące imiona lub nazwiska. W konsekwencji osoby takie rezygnowały z bycia Polakami i wyjeżdżały za Odrę. Podobna sytuacja miała miejsce wśród Mazurów. Natomiast na Dolnym Śląsku nie było tak licznej grupy

42 Archiwum Państwowe w Legnicy, Zarząd Miejski w Jaworze, sygn. 34, Pismo starosty jaworskiego do wójta gminy Mściwojów w sprawie zmiany imion i nazwisk, 14 I 1949, k. 5. 
ludności rdzennej, jak we wspomnianych wcześniej regionach, a zatem akcja spolszczania personaliów nie miała tak masowego charakteru.

\section{BIBLIOGRAFIA (REFERENCES)}

\section{Materiały źródłowe}

Archiwum Państwowe w Katowicach, Śląski Urząd Wojewódzki, Wydział Administracyjno-Prawny, sygn. 79.

Archiwum Państwowe w Legnicy, Zarząd Miejski w Jaworze, sygn. 34.

Archiwum Państwowe we Wrocławiu, Urząd Wojewódzki Wrocławski, sygn. V/174.

Okólnik nr 22/48 z dnia 8 maja 1948 r. o zmianie i ustalaniu imion i nazwisk.

\section{Prasa}

Nie chca niemieckich imion i nazwisk, "Słowo Polskie” 7 III 1947, 64.

Niejaki X, Złowrogie imiona, „Dziennik Zachodni” 22 III 1945, 39.

Odzyskane ziemie czekaja na Polaków, „Dziennik Polski” 2 VII 1945, 145.

Pokłosie zjazdu oświatowego w Łodzi, „Dziennik Polski” 2 VII 1945, 145.

W sprawie nauczania języka niemieckiego, „Rzeczpospolita” 1 VI 1945, 144.

\section{Opracowania}

Borek H., Wśród ślaskich nazw, Opole 1986.

Borisenok E.Yu., Fenomen sovetskoj ukrainizatsii. 1920-1930-e gg., Moskva 2006.

Borisenok E.Yu., Kontseptsii «ukrainizatsii» $i$ ikh realizatsiya $v$ natsional'noj politike $v$ gosudarstvakh vostochnoevropejskogo regiona (1817-1941 gg.), avtoreferat dissertatsii na soiskanie uchenoj stepeni doktora istoricheskikh nauk (na pravakh rukopisi), Moskva 2016, http://inslav.ru/images/stories/other/aspirantura/borisenok/borisenok_avtoreferat. pdf [dostęp: 7 I 2018].

Chistyakov O.I., Korenizatsiya gosudarstvennogo aparata natsional'nykh rajonov v pervye gody sovetskoj vlasti: Po materialam natsional'nykh rajonov Srednego Povolzh'ya, „Prabovedenie" 1965, 1.

Linek B., Polityka antyniemiecka na Górnym Ślasku w latach 1945-1950, Opole 2014.

Malec M., Imię w polskiej antroponimii i kulturze, Kraków 2001.

Nowak J., Kronika miasta i powiatu Tarnowskie Góry: najstarsze dzieje Ślaska i ziemi Bytomsko-Tarnogórskiej: dzieje pierwszego górnictwa w Polsce, Tarnowskie Góry 1927.

Stownik imion wspótcześnie używanych, red. K. Rymut, Kraków 1995.

\section{ABSTRACT}

The aim of this article is to outline the enforced changes of names and surnames in Lower Silesia as a way in which the Polish authorities sought to erase the vestiges of German culture after the end of World War II. Various historical processes contributed to the fact that many inhabitants of Lower Silesia had German or German-sounding names. A number of documents produced at the level of the poviate and the voivodeship indicate that the procedure of changing the German-sounding names to Polish ones was illegal. Firstly, the process was initiated by a circular of the Ministry for Recovered Territories rather than an Act of Parliament. Secondly, the change was enforced by officials at various levels of administration, and compliance was ensured by means of administrative 
sanctions, fines, or in some cases interventions into the private lives of citizens. The change of names and surnames in the Recovered Territories was part of the anti-German policy of the authorities of post-World War II Poland, where anything associated with Germany was to be eradicated.

Key words: Recovered Territories, Silesia, change of names and surnames, indigenes

\section{NOTA O AUTORZE}

Anna Jankowska-Nagórka - doktor nauk humanistycznych w zakresie historii XX w. Jej zainteresowania badawcze to: Śląsk, Ziemie Odzyskane, zmiana imion i nazwisk, zmiana nazw miejscowości, problemy narodowościowe w Polsce po II wojnie światowej. E-mail: ajanag@o2.pl 